\title{
Impact of Street Vendors (PKL) Activities Towards Utilization of Public Space In Losari Beach, Makassar City
}

\author{
1st Idham Irwansyah Idrus \\ Departemen of Sociology \\ Faculty of Social Science \\ Universitas Negeri Makassar \\ Makassar, Indonesia \\ idhamirwansyah@unm.ac.id
}

\author{
2st Jumadi \\ Departement Sociological Science \\ Faculty of Social Science \\ State University of Makassar \\ Makassar, Indonesia \\ Jumadi@unm.ac.id
}

\author{
3st Mario S. Manra \\ Departement of Sociology \\ Faculty of Social Science \\ Universitas Negeri Makassar \\ Makassar, Indonesia \\ emesem@gmail.com
}

\begin{abstract}
This study aims to determine the characteristics of street vendors and what are the impacts of PKL activities on the use of public space in Losari Beach, Makassar City. For this reason, the author uses descriptive analysis method with a qualitative approach. Data were collected through field notes, in-depth personal interviews, direct observations and documentary reviews so as to triangulate the evidence. As in other cities, people in Makassar City choose locations to trade by utilizing the city's potential public space. In the activity of the street vendors, they use the public space of the city such as sidewalks, road bodies and the courtyard of shops. The use of public space has become a characteristic that is identical with the existence of street vendors. But on the other hand public spaces are also used by other user groups, which also require space for their activities in the public space. One of the main public spaces in the city of Makassar is the Losari beach that has been reclaimed and revitalized to increase public space which is cleaner and far from being slum, of course, contrary to the presence of street vendors. The existence of street vendors on the Losari beach platform that is not in accordance with its designation because it utilizes public space will have a social impact on the merchant itself and for other residents of the public space users.
\end{abstract}

Keywords-Characteristics of street vendors (PKL).

\section{INTRODUCTION}

The population growth of Makassar city compared to other cities in Indonesia is quite high, in 1990 the population of Makassar city 944,372 inhabitants, in 2000 totaled $1,130,384$ people, in 2010 totaled 1,339,374 inhabitants, and in 2016 the population of the city of Makassar was more than 1.7 million people (http://makassar.go.id). The high rate of growth of the population is caused by the high rate of birth and increasing urbanization. One of the main problems of the high rate of population growth in urban areas is the development of informal sectors, namely street vendors.

Since the economic crisis in Indonesia in 1998 many economic activities have tended to shift to the informal sector. The informal sector economic activity is one of the street vendors. It can be seen that almost all major cities in Indonesia are growing very rapidly. Especially during the monetary crisis caused many industries to go out of business, resulting in many termination of employment. This in turn increases new unemployment, which will emerge new phenomena of street vendors as a way out of unemployment.

The ability of the informal sector to accommodate workers is supported by existing factors. The main factor is the nature of this sector which does not require requirements and skill levels, the working capital sector, education or facilities used are all simple and easily accessible to all community members or those who do not have a job can be involved in it. One sector that is now the concern of the South Sulawesi government is the informal labor sector. This informal work sector operates in certain places in every crowded city of Makassar.

The existence of street vendors (PKL) on the one hand can improve the lives of those who are in the informal sector, and in general have an impact on economic growth. However, on the other hand the existence of street vendors is a classic problem of big cities in the world, especially cities in developing countries or third world countries. Among other things, the problems caused by PKL, namely the improper use of public space, in addition to being harmful can also harm other public users of public space. The existence of PKL makes the urban spatial structure chaotic, because the city's vision mostly emphasizes the aspects of cleanliness, beauty, and neatness of the city. And, street vendors sometimes cause social insecurity, among others in the form of unfair competition, both among fellow street vendors and conflicts between street vendors and other legal and permanent traders.

Meetings and interactions in the public space, in locations outside the boundaries of the neighborhood, can increase the sense of trust that is associated with the overall spatial community.[1]-[3] Thus, it is important to consider not only the role of shared locations within administratively determined limits but also the potential for public contact in all locations of larger joint routine activities. The consequences of spatial aspects are very clear, namely the increasing demands for space to accommodate the facilities or physical structures needed to carry out these activities. The problem faced by city governments everywhere is the same, namely the limited space supply that can be utilized to 
accommodate new activity infrastructure. This will be a challenge because the increase in demands is precisely accompanied by the amount of unstable cultural, political and economic influences that have resulted in and continue to produce different uses of public space [4]-[6].

One of the popular public spaces in Makassar City is the Losari Beach Pavilion, even Losari beach has always been an icon of Makassar City and South Sulawesi. In November 2004 the Losari beach reclamation began based on the Makassar City Regional Regulation No. 15/2004, with the aim of developing public spaces for Makassar city residents. Losari Beach after reclamation seemed cleaner, far from being a slum. Losari Beach as a public space has quite complete site furniture in the form of park benches, garden lights, suggestion boards, street lights, trash bins and stops. The grounds of Losari beach every night are filled with rows of street vendors selling various kinds of food such as Pisang Epe', various noodles, seafood, and others.

Street Vendor Activities (PKL) are determined by economic actions which are social actions. In other words, the behavior of economic actors is based on the norms / values internalized through socialization. In this condition, actors tend to compromise and obey the prevailing social rules. Although it is necessary to question whether the actor is only passive, this thought at least shows that the actor's actions are not necessarily oriented towards economic / national goals. This economic goal can be estimated related to the social relations that exist between the street vendors and other actors (eg suppliers and other customers). According to Weber, economic actions can be seen as social actions as long as they pay attention to the behavior of others[7]-[9].

The existence of street vendors on the Losari beach platform that is not in accordance with its designation because it utilizes public space will have a social impact on the merchant itself and for other residents of the public space users. The conflict between the interests of life and the interests of the government will clash strongly and cause friction between the two, however the PKL is also a citizen who must be protected by his rights, the right to life, freedom of work, association and assembly.

\section{METHOD}

This type of research is qualitative research. The location of this study is Losari Beach Makassar City. The withdrawal of informants in the study was done by purposive sampling. In this study, researchers used observation, interview and documentation data collection techniques. The analysis technique used is qualitative data analysis techniques, are descriptive (prior analysis in the field and data analysis in the field). The subject of this research is Street Vendors at Losari Beach Pavilion, Makassar City. The withdrawal of informants in the study was carried out by purposive sampling with criteria, namely: PKL who sell for 5 years at the Losari Beach Pavilion. Determination of the duration of trading for more than 5 years, with the consideration that the period of economic conditions both at national, regional and international levels experienced very high dynamics. For example, the economic crisis that hit Indonesia and the world in recent years, the implementation of the free market in
2015: the MEA (Asean Economic Community), AC-FTA (ASEAN China Free Trade Agenda)..

\section{RESULT AND DISCUSSION}

\section{A. Characteristics of Street Vendors (PKL) on Losari Beach}

Based on the results of observations and in-depth interviews of all informants it is known that there are several forms of PKL characteristics on Losari Beach:

1) The form of business street vendors in general is a family business whose management involves all family members. Interestingly because there was one informant who was the second generation who traded on Losari Beach, according to his confession, even though his parents were also street vendors but he had been able to develop the business from semipermanent to semi-permanent. Its physical facilities are in the form of semi-permanent stalls, where carts are arranged lined with plastic tables and chairs, roofed with water-proof tents. There are also some semi-permanent street vendors or traveling traders who sell merchandise with baskets or small carts. Their income varies, depending on holidays and events that take place on Losari beach. On weekends, on average they can get a turnover of IDR 500,000 IDR $1,000,000$, while on other days they only range from IDR 100,000 to IDR 250,000.

2) Types of street vendors selling commodities in general are ready-to-consume foods, among others, Pisang Epe ', various noodles, seafood, various drinks, juice, fruit ice, green banana ice, and others. There are also street vendors who sell non-food items, such as ready-made clothes, toys, dolls. Some street vendors are seen offering services to visitors, such as clowns, where visitors can take pictures with clowns who appear with various superhero characters. Or those who offer photos with various reptiles and other pets. The Makassar City Government, in this case the Losari Beach Management Unit, has divided the placement of street vendors based on the type of business. Food vendors are specifically placed at Anjungan Mandar, street vendors who sell non-food products are placed in the Makassar Pavilion, and street vendors who sell services are scattered in the Bugis Pavilion.

3) Based on local origin, street vendors at Losari Beach are very varied from various regions in South Sulawesi, East Java and Central Java. However, it is more dominated by Makassarese who come from Makassar City, Gowa Regency and Takalar Regency. The difference in background does not cause conflict between them, so far, even if there is a conflict, only about market competition in seizing buyers. But conflicts that arise can always be resolved peacefully. To fight for the common interests of PKL, they are members of the Losari Beach PKL Association. They 
realize that without being together through institutions, namely associations, will not be able to fight for interests, especially so that they can always trade in the Losari Beach area.

4) 4) From the aspect of education, in general PKL only attends the highest level of education to the senior high school level, with variations among others who only graduated from elementary school and others only graduated from junior high school. The low education makes it difficult for them to enter the formal sector, however, they have a high awareness of the importance of education so they hope their children can continue their education to the highest level.

According to McGee \& Yeung the characteristics of PKL activities can be categorized according to the type of commodity, namely:

- Unprocessed and semiprocessed foods, such as meat, fruit, vegetables, rice, and so on.

- Prepared foods, consisting of ingredients that can be consumed immediately, usually in the form of food and drinks.

- Nonfood items, this type of merchandise is broader in scope and is usually not in the form of food, for example textiles to medicines, and others.

- Services, which are included in the service category, such as shoe shine, haircut[10].

McGee \& Yeung (1977), also argued that the service pattern of street vendors could be based on the nature of the service of trading in a moving or settled manner. PKL is classified into three types according to the nature of its services, namely:

- Mobile street vendors, move, and move from one place to another.

- Semi-static street vendors, at a fixed time with selling time that does not necessarily depend on the possibility of the number of consumers, after completing the move immediately.

- Static PKL, selling settled in a certain place in the public space.[11]

Impact of PKL activities on the use of public space on Losari Beach.

1) Social Impact

Visitors are encouraged to visit Losari Beach with a variety of purposes to utilize the social function of the public space, namely as a place of recreation, business, socialization and interaction. In general, visitors come in groups, both family, neighbors, groups of schoolmates/classmates, and colleagues. Losari beach visitors consider the existence of street vendors making it easier for them to enjoy a variety of food and drinks. However, they also said the need to improve the PKL area so as not to appear slum.

Another social impact caused by the presence of street vendors on Losari Beach is the increase in employment. Currently there are approximately 160 street vendors on Losari Beach, on average, every trader employs 3 workers. There are at least 500 workers who are absorbed at the Losari Beach Pavilion, not other occupational fields around it, such as parking attendants.
The influence of population growth in the era of globalization continues to increase significantly, compounded by rapid migration from rural areas to urban centers. This increasingly rapid rate of urbanization has caused employment problems. The amount of urban labor increases faster than the work produced in the urban economic sector such as manufacturing and services. So city centers cannot provide employment for all formal workers, they then look for opportunities to earn a living, they then look for other opportunities in the informal sector of urban settlement. According to Panwar (2015) the informal sector is an important part of the economy and the labor market in many countries, especially in developing countries. PKL plays a major role in job creation, production and income generation. In this informal labor sector, street vendors play an important role in hiring migrants.

2) Economic impact

This study found that street vendors contribute to their main economic development in the city of Makassar by creating jobs, providing alternative income sources, especially lower middle class families and providing lowcost products for low-income groups. The presence of PKL is also an attraction for Losari Beach visitors because it provides economic value for them.

3) Cultural impact

Losari beach reclamation brings a big change in terms of culture, not only in spatial planning but also on the mentality of everyone who uses the Losari beach as a public space. that the development of public spaces from untreated and morally degraded areas. Losari Beach is currently developed using cultural themes, including the use of locally-characterized names, such as the Bugis Pavilion, the Mandar Pavilion and the Makassar Pavilion. The use of artistic ornaments in each platform that represents local culture has contributed to strengthening the integrity of the community, especially visitors to Losari Beach. The concept developed by the Makassar City Government on Losari Beach is certainly contrary to the existence of street vendors who are seen halfheartedly being accommodated, so that the impression of slums is very clearly visible.

One of the conditions for accommodating street vendors in Losari Beach is the commitment of traders to maintain cleanliness around the place they sell, this of course will accustom them to living clean so that over time it will make cleanliness a new culture.

Based on the results of the study, it is known that social behavior of instrumental rationality has been formed by utilizing losari beach public space as a means to achieve the objectives to be achieved through several reasons or rational considerations. In the Weberian perspective, the course of each person in modern times is set within the tightening parameters of instrumental, means-end rationality (of the market or of bureaucracy) with the disciplines emanating from the forces of rationalization tending towards 'a universal phenomenon [which] will make irresistible headway in ever y sphere of human life'.

PKL mobility on sidewalks that may move, diverse demographic settings, and various types and forms of business, so that street vendors can be uniquely positioned to improve urban resilience. For this reason, it is necessary to 
develop social roles that have been played by street vendors to help the city government reduce the impact, we must ensure that their struggle gets proper attention every day. When street vendors' rights on the sidewalk are threatened, not only are their livelihoods in danger, but the city loses their potential. Let's build on existing infrastructure by facilitating strategic partnerships that will portray, legitimize, and enable street vendors to work alongside other formal sectors in urban areas. It is time for the Regional Government and other general public to stop treating street vendors as a threat and threat. Even according to Lapalme the government should recognize their latent potential as social infrastructure that can be accessed quickly that can answer existing and future needs.

\section{CONCLUSION}

If it is said that function and the role of local values in the process of indigenization in the world of education as well as ethno pedagogic. It is considered necessary to integrate learning process according to Douch (Kesuma, 2016: 43), there are three forms of values that can be integrated in the learning process:

First, teachers can give examples of local (local-values) based on the true events to illustrate more alive topic according to the existence and the material being presented. Second, in the form of environmental exploration activities. This process will lead students to learn contextually (contectual teaching and learning). Contextual learning in a constructive paradigm is considered more quick to be accepted by students or university students than those who are taught through theories or understanding

Third, it is a case study about social environment which is discussed deeply. One act teachers are required to do in this case is providing cases aboutthe decrease of understanding and practice of local culture so that unexpected event occurred philosophically, then it is asked to analyze the causes and gain solutions to the problem by referring to local values owned by the community where they live.

\section{ACKNOWLEDGMENT}

We would like to say thank you to the informants, especially lesbians who have spent a lot of time in conducting research. to the Faculty of Social Sciences, Makassar State University, which has facilitated this conference, without this activity and the support of several parties, this paper cannot be completed.

\section{REFERENCES}

[1] C. Smith-Morris, "Epidemiological placism in public health emergencies: Ebola in two Dallas neighborhoods," Soc. Sci. Med., vol. 179, pp. 106-114, 2017.

[2] L. Natarajan, "Socio-spatial learning: A case study of community knowledge in participatory spatial planning," Prog. Plann., vol. 111, pp. 1-23, 2017.

[3] S. Yoo and D. H. Kim, "Perceived urban neighborhood environment for physical activity of older adults in Seoul, Korea: A multimethod qualitative study," Prev. Med. (Baltim)., vol. 103, pp. S90-S98, 2017.
[4] G. Jerome, I. Mell, and D. Shaw, "Re-defining the characteristics of environmental volunteering: Creating a typology of community-scale green infrastructure," Environ. Res., vol. 158, pp. 399-408, 2017.

[5] S. Misra, R. Goswami, T. Mondal, and R. Jana, "Social networks in the context of community response to disaster: Study of a cyclone-affected community in Coastal West Bengal, India," Int. J. Disaster Risk Reduct., vol. 22, pp. 281-296, 2017.

[6] T. Sofield, J. Guia, and J. Specht, "Organic 'folkloric' community driven place-making and tourism," Tour. Manag., vol. 61, pp. 1-22, 2017.

[7] I. Schäufele and U. Hamm, “Consumers' perceptions, preferences and willingness-to-pay for wine with sustainability characteristics: A review," J. Clean. Prod., vol. 147, pp. 379-394, 2017.

[8] Y. Xie, R. Qiao, G. Shao, and H. Chen, "Research on Chinese social media users' communication behaviors during public emergency events," Telemat. Informatics, vol. 34, no. 3, pp. 740-754, 2017.

[9] B. Hansjürgens, C. Schröter-Schlaack, A. Berghöfer, and N. Lienhoop, "Justifying social values of nature: Economic reasoning beyond self-interested preferences," Ecosyst. Serv., vol. 23, pp. 9-17, 2017.

[10] A. Sitepu, "Role of Social Workers in Facilitating of the Poverty Alleviation Program in Indonesia," Asian Soc. Work J., vol. 2, no. 1, pp. 1-14, 2017.

[11] C. Lay, "Volunteers from the Periphery (Case Studies of Survivors of the Lapindo Mudflow and Stren Kali, Surabaya, Forced Eviction)," Southeast Asian Stud., vol. 6, no. 1, pp. 31-61, 2017. 